$\begin{array}{rr}\text { JURNAL } & \text { Volume } 15, \text { Nomor 6, November 2019 } \\ \text { FIT(1)PATOLOGI } & \text { Halaman 248-254 } \\ \text { I N D ON E S A } & \text { DOI: } 10.14692 / \text { jfi.15.6.248-254 } \\ \text { ISSN: } 0215-7950 & \end{array}$

TEMUAN PENYAKIT BARU

\title{
Infeksi Alami Pepper Yellow Leaf Curl Virus dan Sweet potato virus C Pada Ubi Jalar di Malang, Jawa Timur
}

\author{
Natural Infection of Pepper Yellow Leaf Curl Virus and Sweet potato \\ virus $\mathrm{C}$ on Sweet potato in Malang, East Java
}

\author{
Tri Asmira Damayanti ${ }^{1 *}$, Anastasya Hondo ${ }^{1}$, Yusmani Prayogo ${ }^{2}$ \\ ${ }^{1}$ Institut Pertanian Bogor, Bogor 16680 \\ ${ }^{2}$ Balai Penelitian Aneka Kacang dan Umbi, Malang 65162
}

\begin{abstract}
ABSTRAK
Gejala tulang daun kuning (vein yellowing) dan malformasi daun yang diduga disebabkan oleh virus ditemukan pada ubi jalar IR Melati di daerah Kendalpayak, Malang, Jawa Timur. Amplifikasi DNA/cDNA menggunakan primer universal Begomovirus, Potyvirus, dan Cucumovirus menunjukkan positif teramplifikasi DNA dengan primer universal Begomovirus, dan Potyvirus, namun negatif dengan primer universal Cucumovirus. Berdasarkan runutan sikuen nukleotida, gejala tulang daun kuning dan malformasi daun disebabkan oleh infeksi ganda Pepper yellow leaf curl virus (PYLCV) dan Sweet potato virus $\mathrm{C}$ (SPVC). Analisis identitas DNA dengan perangkat lunak BioEdit menunjukkan homologi paling tinggi sebesar $98.5 \%$ terhadap PYLCV isolat cabai dari Bangli Bali, dan sebesar 98\% terhadap SPVC dengan isolat ubi jalar asal Jepang dan Amerika Serikat. Laporan ini merupakan temuan baru infeksi alami PYLCV dan SPVC pada ubi jalar di Indonesia.
\end{abstract}

Kata Kunci: cylindrical inclusion, Begomovirus, infeksi ganda, ubi jalar

\begin{abstract}
Virus-like infection with vein yellowing and leaf malformation symptoms were observed on sweet potato IR Melati at Kendalpayak, Malang, East Java. Amplification of DNA/cDNA was carried out using universal primer of Begomovirus, Potyvirus and Cucumovirus showed successfully amplified by universal primer of Begomovirus and Potyvirus, while negatively to universal primer of Cucumovirus. Based on nucleotide sequences, the vein yellowing and leaf malformation symptoms on sweet potato caused by double infection of Pepper yellow leaf curl virus (PYLCV) and Sweet potato virus C (SPVC). DNA identity analysis using BioEdit software showed highest homology up to $98.5 \%$ to one of PYLCV isolates from Bali, and up to $98.0 \%$ to sweet potato isolate of SPVC from Japan and USA. This is a new finding of natural infection of PYLCV and SPVC on sweet potato in Indonesia.
\end{abstract}

Key words: cylindrical inclusion, double infection, geminivirus, sweet potato

*Alamat penulis korespondensi: Departemen Proteksi Tanaman, Fakultas Pertanian, Institut Pertanian Bogor. Jalan Kamper, Kampus IPB Dramaga, Bogor 16680.

Tel.0251-8629364, Faks.0251-8629362, Surel: triadys@apps.ipb.ac.id 
Ubi jalar (Ipomoea batatas) merupakan salah satu komoditas pangan penting di Indonesia. Selain sebagai sumber karbohidrat, ubi jalar juga mengandung nutrisi yang bermanfaat bagi kesehatan dan menjadi salah satu komoditas pilihan untuk penganekaragaman pangan. Diversifikasi pangan menjadi jalan keluar rasional bagi pemecahan masalah pemenuhan kebutuhan pangan (Pusdatin Pertanian 2016).

Kontribusi Indonesia sebagai produsen ubi jalar menduduki urutan ke 6 di dunia. Sentra produksi ubi jalar di Indonesia yang terbesar di Jawa Barat, Papua, Jawa Timur, dan Jawa Tengah. Berdasarkan data, produksi ubi jalar nasional di tahun 2016 mengalami penurunan sebanyak 128319 ton (5.58\%) dari tahun 2015, sedangkan di Jawa Timur penurunan produksi di tahun 2016 sebesar 62477 ton (17.82\%) (Pusdatin Pertanian 2016; BPS 2016). Untuk tetap menjaga dan meningkatkan produktivitas ubi jalar, perlu upaya guna mengatasi faktorfaktor yang membatasi produksi, di antaranya infeksi berbagai jenis patogen, salah satunya ialah virus.

Infeksi virus menjadi salah satu kendala produksi ubi jalar di berbagai negara. Virus yang pernah dilaporkan menginfeksi ubi jalar, yaitu Sweet potato feathery mottle potyvirus (SPFMV), Sweet potato chlorotic stunt virus (SPCSV), dan Sweet potato mild mottle virus (SPMMV), Cucumber mosaic cucumovirus (CMV), Ipomoea yellow vein virus (IYVV), dan Sweet potato latent virus (SwPLV) (Valverde et al. 2007). Di Indonesia, sebelumnya Sweet potato potyvirus G (SPVG) telah dilaporkan menginfeksi ubi jalar di Tana Toraja, Sulawesi Selatan (Anjarsari et al. 2013) dan Sweet potato feathery mottle virus (SPFMV) di Bogor (Hondo et al. 2018). Virus ini sebelumnya dilaporkan menginfeksi ubi jalar di wilayah Afrika, Cina, dan Amerika Serikat (Kokkinos dan Clark 2006). Infeksi Begomovirus pada ubijalar dilaporkan di Kenya, Amerika Serikat dan Brazil disebabkan oleh Sweetpotato leaf curl virus (SPLCV), SPLCV-US (isolat United States) dan SPLCV-SP (isolat Sao Paolo) (Lotrakul et al. 1998; Miano et al. 2006; Albuquerque et al. 2011). Beberapa infeksi virus pada ubi jalar dilaporkan menyebabkan kehilangan hasil seperti infeksi SPFMV sebesar 8090\%, SPVG sebesar 30-40\%, dan SPFMV + SPCSV sebesar 50-98\% (Valverde et al. 2007; Balitkabi 2014).

Baru-baru ini berdasarkan pengamatan di lapangan, ditemukan gejala tulang daun kuning (vein yellowing) dan malformasi daun pada ubi jalar jenis IR Melati di Kendalpayak, Malang (Gambar 1a) dengan insidensi kurang dari 5\%. Gejala tulang daun menguning ini menyerupai gejala vein yellowing pada tanaman babadotan yang disebabkan oleh rekombinasi antara Tomato leaf curl Java virus dengan Ageratum
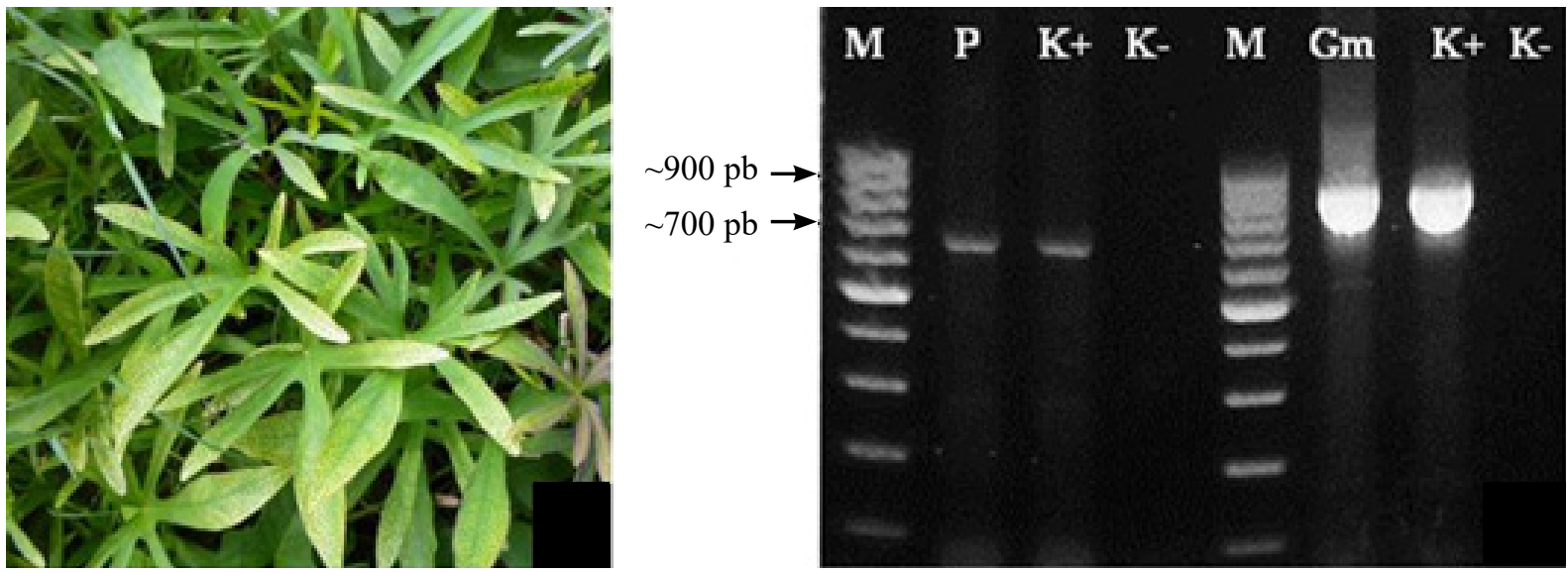

Gambar 1 a, Gejala tulang daun menguning (vein yellowing) pada ubi jalar IR Melati; dan b, DNA hasil PCR dengan primer universal Potyvirus berukuran $\sim 700 \mathrm{pb}$ dan Begomovirus berukuran $\sim 900$ pb. M, Penanda DNA 100 pb (Smobio, Taiwan); P, Potyvirus; Gm, Geminivirus; $\mathrm{K}(+)$, Kontrol positif; dan K(-), Kontrol negatif. 
vein yellowing virus yang sebelumnya dilaporkan oleh Kon et al. (2007). Mengingat ubi jalar sebagai salah satu komoditas pangan yang penting di Indonesia, maka perlu segera dilakukan kajian untuk mendeteksi dan mengidentifikasi virus penyebab gejala tulang daun kuning pada ubi jalar agar dapat menentukan upaya pengelolaan virus yang tepat. Namun, spesies penyebab gejala tulang daun kuning pada ubi jalar belum diketahui, maka deteksi asam nukleat dilakukan dengan menggunakan primer universal Begomovirus. Selain itu, sebelumnya telah dilaporkan bahwa CMV (Valverde et al. 2007), SPVG dan SPFMV (Anjarsari et al. 2013; Hondo et al. 2018) ada di Indonesia, maka deteksi juga dilakukan dengan menggunakan primer universal Cucumovirus dan Potyvirus.

Total asam nukleat diekstraksi dari $0.1 \mathrm{~g}$ jaringan daun tanaman bergejala. DNA/ RNA total diisolasi dari daun yang bergejala mengikuti prosedur yang dijelaskan oleh Doyle dan Doyle (1987) dengan modifikasi minor perlakuan lisis pada suhu $65{ }^{\circ} \mathrm{C}$ dari 60 menit untuk ekstraksi DNA total, menjadi 30 menit untuk ekstraksi RNA total.

Sintesis cDNA (complementary DNA) dilakukan dalam total volume reaktan $10 \mu \mathrm{L}$ yang terdiri atas $2 \mu \mathrm{L} \mathrm{H}_{2} \mathrm{O}$ bebas nuklease, $0.5 \mu \mathrm{L}$ dNTP $10 \mathrm{mM}, 1 \mu \mathrm{L}$ Oligo d(T) $10 \mu \mathrm{M}$, $2 \mu \mathrm{L}$ bufer RT $5 \mathrm{x}, 0.5 \mu \mathrm{L}$ DTT $0.1 \mathrm{M}$, $0.5 \mu \mathrm{LM}-\mathrm{MuLV}$ (Revertaid, Thermo Scientific, USA), $0.5 \mu \mathrm{L}$ Ribolock (Thermo Scientific, USA), dan $3 \mu \mathrm{L}$ RNA total. Transkripsi balik RNA dilakukan pada suhu $42{ }^{\circ} \mathrm{C}$ selama 60 menit dan pada suhu $70{ }^{\circ} \mathrm{C}$ selama 10 menit untuk inaktivasi enzim. Siapan cDNA selanjutnya digunakan sebagai cetakan dalam reaksi PCR (Anjarsari et al. 2013).

Amplifikasi DNA virus dilakukan dengan sepasang primervirustargetmenggunakan PCR Master mix 2X Dream Taq Green Polymerase (Thermo Scientific, USA). Adapun komposisi reaktan dibuat sesuai dengan anjuran pembuat enzim dengan total volume reaksi $25 \mu \mathrm{L}$. cDNA/DNA diamplifikasi dengan teknik PCR dengan volume reaksi $25 \mu \mathrm{L}$ yang terdiri atas $8.5 \mu \mathrm{L}$ air bebas nuklease, $12.5 \mu \mathrm{L} 2 \mathrm{X}$ Dream Taq Green polymerase (Thermo Scientific, USA), masing-masing $1 \mu \mathrm{L} 10 \mu \mathrm{M}$ primer forward dan primer reverse, dan $2 \mu \mathrm{L}$ cDNA.

Amplifikasi cDNA dengan PCR menggunakan primer universal Potyvirus (CIREV dan CIFOR) mengamplifikasi secara parsial gen CI (cylindrical inclusion) dengan amplikon berukuran $\sim 700 \mathrm{pb}$, primer universal Cucumovirus mengamplifikasi secara parsial gen selubung protein dengan amplikon berukuran $\sim 382 \mathrm{pb}$ dan primer universal Begomovirus yang mengamplifikasi secara parsial open reading frame (ORF) $\mathrm{AC} 1$ dan $\mathrm{AC} 2$ yang menginfeksi ubi jalar dan begomovirus lainnya dengan amplikon berukuran $\sim 900 \mathrm{pb}$. Program PCR yang digunakan ditabulasikan pada Tabel 1.

DNA hasil PCR diseparasi dalam gel agarosa $1 \%$ yang dilarutkan dalam bufer TBE 0.5x. Larutan gel agarosa didinginkan hingga suhu $50{ }^{\circ} \mathrm{C}$ selama kurang lebih 15 menit, lalu ditambahkan pewarna asam

Tabel 1 Kondisi amplifikasi cDNA dan DNA menggunakan PCR untuk masing-masing pasangan primer universal

\begin{tabular}{|c|c|c|c|c|c|}
\hline Primer & $\begin{array}{c}\text { Pra- } \\
\text { denaturasi }\end{array}$ & Denaturasi & Penempelan & Pemanjangan & $\begin{array}{c}\text { Pemanjangan } \\
\text { akhir }\end{array}$ \\
\hline \multicolumn{6}{|l|}{ cDNA } \\
\hline $\begin{array}{l}\text { Potyvirus (CIREV } \\
\text { dan CIFOR)* }\end{array}$ & $94^{\circ} \mathrm{C}, 3^{\prime}$ & $40 \mathrm{x}$ siklus, $94^{\circ} \mathrm{C}, 1^{\prime}$ & $40^{\circ} \mathrm{C}, 30^{\prime \prime}$ & $68^{\circ} \mathrm{C}, 1^{\prime}$ & $68^{\circ} \mathrm{C}, 5^{\prime}$ \\
\hline $\begin{array}{l}\text { Cucumovirus (CMV- } \\
1 \mathrm{~F} \text { dan } 1 \mathrm{R})^{* *}\end{array}$ & $94^{\circ} \mathrm{C}, 2^{\prime}$ & $\begin{array}{c}35 \times \text { siklus, } 93.5^{\circ} \mathrm{C}, \\
45^{\prime \prime}\end{array}$ & $55^{\circ} \mathrm{C}, 45^{\prime}$ & $72^{\circ} \mathrm{C}, 1^{\prime}$ & $72^{\circ} \mathrm{C}, 5^{\prime}$ \\
\hline \multicolumn{6}{|l|}{ DNA } \\
\hline $\begin{array}{l}\text { Begomovirus SPG1 } \\
\text { dan SPG2*** }\end{array}$ & $94^{\circ} \mathrm{C}, 5^{\prime}$ & $35 x$ siklus, $94^{\circ} \mathrm{C}, 1^{\prime}$ & $50^{\circ} \mathrm{C}, 1$ & $72^{\circ} \mathrm{C}, 1$ & $72^{\circ} \mathrm{C}, 7^{\prime}$ \\
\hline
\end{tabular}




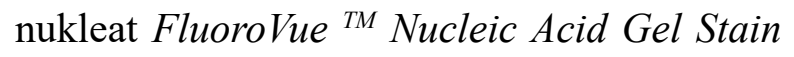
(Smobio, Taiwan). Elektroforesis dilakukan pada tegangan $100 \mathrm{~V}$ selama 20 menit. Hasil elektroforesis selanjutnya divisualisasi di bawah transilluminator ultraviolet dan didokumentasi.

DNA hasil PCR dikirim ke First Base Malaysia untuk perunutan nukleotida. Hasil perunutan nukleotida digunakan untuk mengetahui tingkat kesamaan nukleotida dengan runutan nukleotida yang terdapat di GenBank menggunakan program BLASTn (basic local alignment search tool nucleotide). Identitas matriks homologi sikuen dianalisis dengan peranti lunak BioEdit, dan pohon filogenetika dianalisis dengan peranti lunak MEGA v6.0 menggunakan bootstrap 1000 kali.

Hasil PCR menunjukkan DNA amplikon teramplifikasi berukuran $\sim 900 \mathrm{pb}$ dengan primer universal Begomovirus dan $\sim 700 \mathrm{pb}$ dengan primer universal Potyvirus (Gambar 1b), namun tidak ada DNA yang teramplifikasi dengan primer universal Cucumovirus (data tidak ditampilkan). Hal ini menunjukkan bahwa gejala tulang daun kuning pada ubi jalar IR Melati merupakan infeksi ganda antara Potyvirus dan Begomovirus.

Berdasarkan hasil perunutan DNA, menunjukkan bahwa Begomovirus yang menginfeksi ubi jalar berhasil terunut secara parsial sepanjang 825 nukleotida (nt) dan mengkode 275 asam amino (aa) dan teridentifikasi sebagai Pepper yellow leaf curl virus (PYLCV). PYLCV tersebut memiliki homologi nukleotida dan asam amino tertinggi berturut-turut sebesar $98.5 \%$ dan $96.9 \%$ terhadap PYLCV isolat cabai merah dari Bangli (Bali) (Tabel 2). Analisis filogenetika berdasarkan runutan basa nukleotida menunjukkan bahwa PYLCV isolat ubi jalar dari Malang berada pada kelompok yang sama dengan beberapa isolat PYLCV dari Bali dan Bogor (Gambar 2a).

Potyvirus yang menginfeksi bersama PYLCV pada ubi jalar IR Melati teridentifikasi berdasarkan urutan gen CI parsial sepanjang 693 nt yang mengkode 231 asam amino dan teridentifikasi sebagai Sweet potato virus C (SPVC); similaritas sikuen nukleotida dan asam amino tertinggi dengan SPVC isolat dari Jepang dan Amerika Serikat berturutturut ialah sebesar 98\% dan 99.5\% (Tabel 3). Analisis filogenetika berdasarkan urutan basa nukleotida menunjukkan bahwa SPVC isolatubi jalar dari Malang berada pada kelompok yang sama dengan SPVC isolat Jepang dan Korea, serta isolat dari negara lainnya (Gambar 2b).

PYLCV merupakan virus penting pada pertanaman cabai dan tomat yang menyebabkan kehilangan hasil cabai di Sumatera Barat mencapai 100\% dan $44.48 \%$ pada tomat di Kabupaten Gianyar, Bali (Trisno et al. 2010; Mahendra et al. 2017). PYLCV memiliki kisaran inang yang luas meliputi Solanaceae, Compositae dan beberapa famili Leguminosae. Penularan PYLCV pada percobaan di rumah kaca menunjukkan bahwa tanaman dari famili Leguminosae berpotensi sebagai inang alternatif PYLCV, walaupun intensitas serangannya lebih ringan dan masa

Tabel 2 Homologi basa nukleotida dan asam amino Pepper yellow leaf curl virus isolat ubi jalar dari Malang terhadap isolat lainnya

\begin{tabular}{cccc}
\hline \multirow{2}{*}{ Virus Isolat } & \multicolumn{2}{c}{ Homologi (\%) } & \multirow{2}{*}{ No. aksesi } \\
\cline { 2 - 3 } & $\mathrm{nt*}$ & $\mathrm{aa} * *$ & \\
\hline PYLCV_Idn_Bangli a1 & 98.5 & 96.9 & LC381264.1 \\
_Idn_Perean 2 & 97.8 & 95.0 & LC381263.1 \\
_Idn_Talibeng 1 & 96.4 & 92.0 & LC381258.1 \\
_Idn_Telaga Tawang 2 & 96.3 & 91.6 & LC381261.1 \\
_Idn_Telaga Tawang 1 & 96.1 & 91.6 & LC381260.1 \\
_Bogor & 95.5 & 87.8 & DQ083764.1 \\
SPLCV_Korea Selatan & 64.4 & 34.9 & KT992067.1 \\
AYVV_Taiwan & 78.3 & 50.7 & KX943290.1 \\
\hline
\end{tabular}

*nt. Nukleotida;** aa. Asam amino; Idn-Indonesia; PYLCV. Pepper yellow leaf curl virus; SPLCV-Sweet potato leaf curl virus dan AYVV-Ageratum yellow vein virus sebagai pembanding. 
a

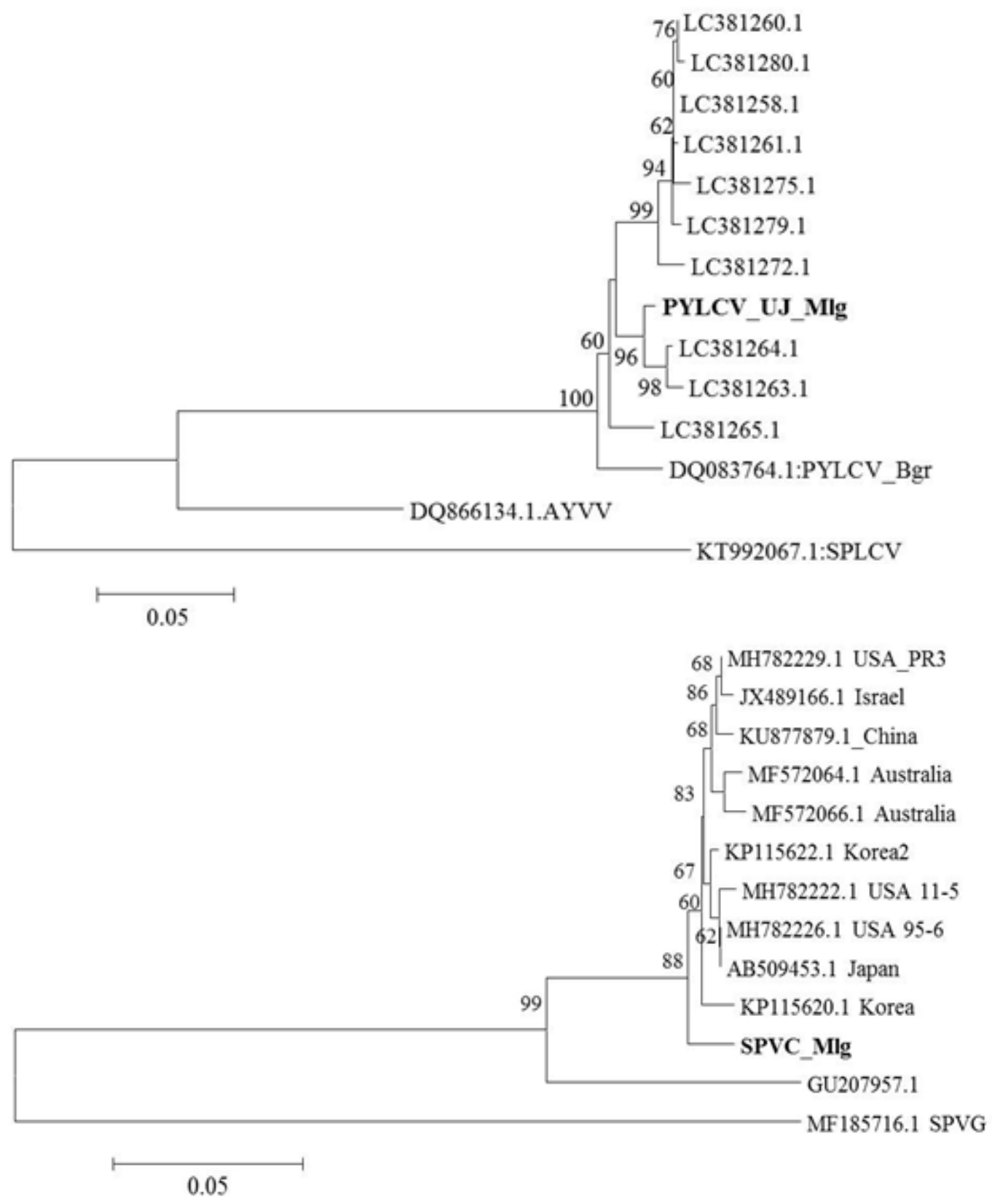

Gambar 2 Analisis filogenetika berdasarkan sikuen nukleotida. a, PYLCV_UJ Mlg; dan b, SPVC-Mlg. Sweet potato leaf curl virus (SPLCV) isolat Korea Selatan, Ageratum yellow vein virus (AYVV) dan Sweet potato virus G (SPVG) digunakan sebagai pembanding. UJ, Ubi jalar; Mlg, Malang.

inkubasinya lebih lama (Sulandari et al. 2006). Infeksi alami PYLCV pada kedelai juga telah dilaporkan oleh Rahim et al. (2015).

Populasi serangga vektor Bemisia tabaci di lapangan pada kondisi lingkungan yang sesuai bagiperkembangan serangga, berperan penting dalam mempercepat penularan dan penyebaran PYLCV. Teridentifikasinya PYLCV pada ubi jalar menunjukkan perluasan inang alami dari virus ini di Indonesia. Sebelumnya, Sweet potato leaf curl virus isolat US (SPLCV-US) dilaporkan menginfeksi ubi jalar di Amerika Serikat dengan gejala keriting daun (Lotrakul et al.1998). Hal ini menunjukkan keberadaan begomovirus yang berbeda spesies dapat menginfeksi ubi jalar.

SPVC merupakan Potyvirus ketiga yang berhasil terdeteksi dan teridentifikasi menginfeksi ubi jalar setelah Sweet potato virus G (SPVG) di Tanah Toraja (Anjarsari et al. 2013) dan Sweet potato feathery mottle virus (SPFMV) di Bogor (Hondo et al. 2018). 
Tabel 3 Hasil perunutan basa nukleotida dan asam amino Sweet potato virus C isolat Malang terhadap isolat dari negara lainnya

\begin{tabular}{cccc}
\hline \multirow{2}{*}{ Virus Isolat } & \multicolumn{2}{c}{ Homologi (\%) } & \multirow{2}{*}{ No. aksesi } \\
\cline { 2 - 3 } & $\mathrm{nt*}$ & $\mathrm{aa}^{* *}$ & \\
\hline SPVC_Jepang & 98.0 & 99.5 & AB509453.1 \\
_USA 95-6 & 98.0 & 99.5 & MH782226.1 \\
_ Cina & 97.6 & 99.5 & KU877879.1 \\
_ USA_PR3 & 97.9 & 99.5 & MH782229.1 \\
_ Korea & 97.6 & 100.0 & KP115620.1 \\
- Australia & 97.4 & 99.5 & MF572064.1 \\
_ Israel & 97.3 & 99.5 & JX498166.1 \\
_Peru & 89.5 & 96.0 & GU207957.1 \\
SPVG_Brazil & 68.9 & 78.8 & MF185716.1 \\
\hline
\end{tabular}

*nt. Nukleotida;** aa. Asam amino; SPVG. Sweet potato virus G sebagai pembanding

Gejala khas infeksi SPVC pada ubi jalar IR Melati tidak jelas karena menginfeksi bersama PYLCV. Gejala infeksi PYLCV berupa vein yellowing (tulang daun menguning) lebih dominan (Gambar 1a).

Berdasarkan hasil identifikasi asam nukleat, gejala tulang daun menguning pada ubi jalar yang ditemukan di Malang disebabkan oleh infeksi ganda antara PYLCV dan SPVC. Ubi jalar menjadi inang baru bagi PYLCV di lapangan berpotensi menjadi pembatas produksi ubi jalar di masa akan datang. Penyebaran virus pada ubi jalar disebabkan oleh adanya sumber virus (ubi jalar sakit) di lapangan, keberadaan serangga vektor di sekitar pertanaman, dan penggunaan bahan tanaman yang telah terinfeksi (Gutierrez et al. 2003). Penggunaan dan penyebaran stek sakit harus dihindari, karena penyebaran virus melalui perbanyakan vegetatif merupakan salah satu metode yang efektif mengabadikan (perpetuating) dan menyebarkan virus (Hull 2014). Oleh karena itu, penggunaan stek sehat dan bebas virus, pengelolaan serangga vektor dan kegiatan deteksi rutin pada tanaman indukan untuk memastikan stek yang akan ditanam bebas virus menjadi tindakan penting untuk pengendalian virus ini.

\section{DAFTAR PUSTAKA}

Albuquerque LCD, Inoue-Nagata AK, Pinheiro B, Ribeiro S, Resende RO, Moriones E, Navas-Castillo J. 2011.
A novel of monopartite Begomovirus infecting sweetpotato in Brazil. Arch Virol. 156(7):1291-1294. DOI: https://doi. org/10.1007/s00705-011-1016-x.

Anjarsari L, Suastika G, Damayanti TA. 2013. Deteksi dan identifikasi Potyvirus pada ubi jalar di Tanah Toraja, Sulawesi Selatan. J Fitopatol Indones. 9(6):193-201. DOI: https://doi.org/10.14692/jfi.9.6.193.

Aramburu J, Galipienso L, Lopez C. 2007. Reappearance of Cucumber mosaic virus isolates belonging to subgroup IB in Tomato Plants in North-Eastern Spain. J Phytopathol. 15(5):513518. DOI: https://doi.org/10.1111/j.14390434.2007.01267.x.

[Balitkabi] Balai Penelitian Tanaman Aneka Kacang dan Umbi. 2014. Penyakit virus tanaman ubi jalar dan upaya pengendaliannya Indonesia. Malang (ID): Balitkabi.

[BPS] Badan Pusat Statistik Provinsi Jawa Barat. 2016. Potensi ubi jalar di Jawa Barat [Internet]. [diunduh: 2017 Okt 2]. Tersedia pada: http://regional investment. bkpm.go.id/newsipid/id/commodityarea. php? $\mathrm{ia}=3201 \& \mathrm{ic}=260$

Doyle JJ, Doyle JL. 1987. A rapid DNA isolation of procedure for small quantities of fresh leaf tissue. Phytochem Bull. 19:11-19.

Gutierrez DL, Fuentes S, Salazar FL. 2003. Sweet potato virus disease (SPVD): distribution, incidence, and effect on 
sweet potato yield in Peru. Plant Dis 87:297-302. DOI: https://doi.org/10.1094/ PDIS.2003.87.3.297.

Ha C, Coombs S, Revill PA, Harding RM, Vu M, Dale JL. 2008. Design and application of two novel degenerate primer pairs for the detection and complete genomic characterization of Potyviruses. Arch Virol. 53(1):25-36. DOI: https://doi. org/10.1007/s00705-007-1053-7.

Hondo A, Damaiyanti KC, Hafizh MF, Amanatillah N, Damayanti TA. 2018. Penyakit bercak kuning ubi jalar di Bogor, Jawa Barat. J Fitopatol Indones. 14(2):6973. DOI: https://doi.org/10.14692/ jfi.14.2.69.

Hull R. 2014. Plant Virology. Fifth Edition. London (UK): Academic Press. DOI: https://doi.org/10.1016/C2010-0-64974-1.

Kokkinos CD, Clark CA. 2006. Real-time PCR assays for detection and quantification of sweet potato viruses. Plant Dis. 9(6):783788. DOI: https://doi.org/10.1094/PD-900783.

Kon T, Kuwabara K, Hidayat SH, Ikegami M. 2007. A Begomovirus associated with ageratum yellow vein disease in Indonesia: evidence for natural recombination between tomato yellow leaf curl Java virus and Ageratum yellow vein virus-[Java]. Arch Virol. 52(6):1147-1157. DOI: https:// doi.org/10.1007/s00705-006-0928-3.

Li R, Salih S, Hurtt S. 2004. Detection of begomoviruses in sweetpotato by polymerase chain reaction. Plant Dis. 88(12):1348-1351. DOI: https://doi. org/10.1094/PDIS.2004.88.12.1347.

Lotrakul P, Valverde RA, Clark CA, Sim J, Torre RD. 1998. Detection of a Begomovirus infecting sweet potato in the United States. Plant Dis. 82(11):1253-1257. DOI: https:// doi.org/10.1094/PDIS.1998.82.11.1253.
Mahendra IBG, Phabiola TA, Yuliadhi KA. 2017. Pengaruh infeksi beberapa virus terhadap penurunan hasil produksi tanaman tomat (Solanum lycopersicum Mill.) di Dusun Marga Tengah, Desa Kerta, Kecamatan Payangan, Kabupaten Gianyar. Agrotek Trop. 6(3):301-309.

Miano DW, LaBonte DR, Clark CA, Valverde RA, Hoy MW, Hurtt S, Li R. 2006. First report of a Begomovirus infecting Sweet potato in Kenya. Plant Dis. 90(6):832. DOI: https://doi.org/10.1094/PD-900832B.

Pusdatin Pertanian. 2016. Outlook komoditas pertanian sub sektor tanaman pangan. Jakarta (ID): Pusat Data dan Informasi Pertanian, Kementan.

Rahim YF, Damayanti TA, Ghulamahdi M. 2015. Deteksi virus yang menginfeksi kedelai di Jawa. J Fitopatol Indones. 11(2):59-67. DOI: https://doi. org/10.14692/jfi.11.2.59.

Sulandari S, Suseno R, Hidayat SH, Harjosudarmo J, Sosromarsono S. 2006. Deteksi dan kajian kisaran inang virus penyebab penyakit daun keriting kuning cabai. Hayati 13(1):1-6. DOI: https://doi. org/10.1016/S1978-3019(16)30371-0.

Trisno J, Hidayat SH, Jamsari, Habazar T, Manti I. 2010. Identifikasi molekuler Begomovirus penyebab penyakit kuning keriting pada tanaman cabai (Capsicum annum L.) di Sumatera Barat. J Natur Indones. 13(1):41-46. DOI: https://doi. org/10.31258/jnat.13.1.41-46.

Valverde RA, Clark CA, Valkonen JP. 2007. Viruses and virus disease complexes of sweet potato. Plant Viruses 1(1):116-126. 